\title{
Fotoalbum Ludevíta Procházky z let 1862 - 1888 / The Procházka Photo Album (1862-1888)
}

K vydání připravili Jana VOJTĚŠKOVÁ, Jiří K. KROUPA. Praha : Národní muzeum \& KLP - Koniasch Latin Press, 2015. LXII + 186 stran. ISBN 978-80-7036-455-0 (NM), ISBN 978-80-87773-29-1 (KLP)

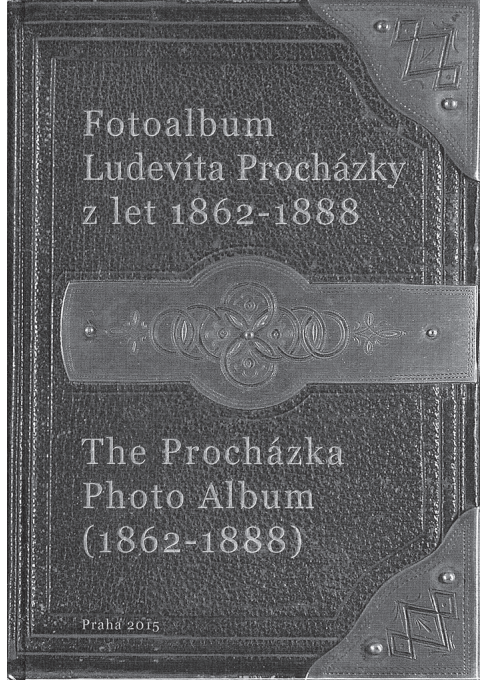

Dva roky po vydaní pramenno-kritickej edície korešpondencie a pamätných zápisov Ludevíta Procházku pripravila Jana Vojtěšková v spolupráci s Jiří K. Kroupom kritické vydanie dalšej Procházkovej pamiatky (2015), ktoré sa tentoraz týkalo problematiky hudobnej ikonografie. Sústredenej práci na vydaní Procházkovho fotoalbumu predchádzal však dlhší časový úsek venovaný výskumným a rešeršným aktivitám súvisiacim s danou témou. Zárukou kvalitnej prípravy edície boli mená oboch osvedčených editorov. Hudobná historička Jana Vojtěšková sa ako vedecká pracovníčka Národního muzea - Českého muzea hudby v Prahe venuje výskumu najmä českých dejín hudby 19. storočia so špeciálnym zameraním na kritické edície prameňov. Historik a muzikológ Jiří K. Kroupa je vedeckým pracovníkom Nadace pro dějiny kultury ve střední Evropě so sídlom v Prahe. Jeho vedecko-výskumná práca má širšie dimenzie a zahrnuje oblast' staršej aj novšej hudobnej kultú- ry v Čechách, ako aj editovanie nenotovaných hudobných prameňov.

Portrétne fotografie $\mathrm{z}$ prezentovaného Procházkovho albumu predstavujú špecifickú kategóriu hudobnej ikonografie. Súvisia $\mathrm{s}$ technickým pokrokom, $\mathrm{v}$ našom prípade špeciálne s vynálezom fotografie, ako aj s vytváraním rôznych zbierok. Historizmus a historické myslenie v 19 . storočí značne ovplyvnili zberatel'ské aktivity milovníkov hudby aj hudobníkov profesionálov a týkali sa v prvom rade hudobných rukopisov, či špeciálne autografov, ale aj iných prameňov so vztahom $\mathrm{k}$ hudbe, medzi nimi najmä korešpondencie hudobníkov a obrazových prameňov. Vdaka rozmachu portrétnej fotografie ako nového fenoménu, ktorý vhodne plnil reprezentačnú, úžitkovú aj spomienkovú funkciu, máme dnes $\mathrm{k}$ dispozícii také jedinečné pramene obrazovej dokumentácie, ako ich obsahuje aj recenzovaná publikácia.

Pramenno-kritická edícia Fotoalbum Ludevíta Procházky z let 1862 - 1888 vznikla ako výsledok spolupráce dvoch pražských inštitúcií Národního muzea - Českého muzea hudby a Nadace pro dějiny kultury ve střední Evropě a jej vydanie opät podporilo Ministerstvo kultúry ČR v rámci inštitucionálneho financovania koncepčného rozvoja výskumnej organizácie Národní muzeum. Vzácnu pamiatku archivuje Národní muzeum - České muzeum hudby - Muzeum Bedřicha Smetany v Prahe. Hned' v úvode publikácie editori explicitne uviedli, že dobové portrétne fotografie z Procházkovho fotoalbumu sú komplementárnym materiálom $\mathrm{k}$ už publikovanému Procházkovmu albumu s korešpondenciou a pamätnými zápismi, a preto základný prístup je založený na podobných východiskách, forme aj grafickom riešení (s. ix). Treba dodat', že v novej publikácii editori nadviazali na Pro- 
cházkov album korešpondencie a pamätných zápisov nielen podobnou koncepciou, grafickým riešením a výtvarnou adjustážou, ale aj vysokou vedeckou úrovňou muzikologických textov, pramenno-kritickej práce a editovania ikonografických prameňov. Reprezentatívnost publikácie opät dotvára jej bilingválny charakter v českej a anglickej mutácii a tlač na kriedovom papieri, čo však bolo nevyhnutným predpokladom pre kvalitnú reprodukciu ikonografických prameňov. Výbornú kvalitu tlače zabezpečilo opät pražské nakladatel'stvo KLP - Koniasch Latin Press.

V publikácii sa zachováva zaužívané a doterajšou edičnou praxou overené členenie na dve časti. V prvej časti v stati Ludevít Procházka a jeho fotoalbum nás editori detailne oboznámili s trochu zložitým procesom vzniku pamiatky (s. xi - xiii). Procházka si začal fotoalbum zostavovat už počas svojho života, zomrel však priskoro vo veku nedovŕšených 51 rokov a zostavenie albumu $\mathrm{z}$ jeho zbierky fotografií iste nepatrilo $\mathrm{k}$ jeho prioritám. Fotoalbum tak dostal dnešnú podobu až v prvej polovici 20. storočia pri inventarizácii a katalogizácii jeho pozostalosti, ked'sa aj iné portrétne fotografie zachované $\mathrm{v}$ jeho osobnom fonde začlenili do albumu, vrátane dalších fotografií mimo inventarizačných jednotiek. Niektoré z nich eventuálne mohli byt pôvodne súčastou Procházkovej korešpondencie. Čast’ fotografií obsahovala venovanie s menom dedikujúceho, niektoré len meno a iné žiadny údaj. Treba vyzdvihnút, že editori odviedli precíznu komparačnú prácu. Museli identifikovat’ a porovnat nielen portréty bez venovania a bez uvedenia mena osoby na fotografii, ale tiež - aj ked' skôr výnimočne - korigovat dodatočnú, pri inventarizácii vzniknutú chybnú identifikáciu osôb na portrétoch. Týkalo sa to napríklad fotografie kremnického sláčikového kvarteta s J. L. Bellom a tromi kremnickými meštanmi milovníkmi hudby. Starší chybný údaj na reverze fotografie „kvartet Hřímalých“ (s. 62 - 63) editori správne korigovali na súčasný aktuálny stav poznania. Iným príkladom je jedna z dvoch fotografií českého estetika Otakara Hostinského, zobrazujúca mladého muža v rokoch dospievania (s. 49). Pri reprodukcii tejto fotografie editori odôvodnene doplnili k menu otáznik. Osobne by som sa priklonila dokonca $\mathrm{k}$ názoru, že miera odlišnosti $\mathrm{v}$ porovnaní so známymi Hostinského portrétmi tu prevažuje nad znakmi podobnosti, čiže pravdepodobne ide o inú osobu.

$\mathrm{V}$ prvej časti publikácie editori dalej minuciózne charakterizovali album so zretelom na rôzne tematické okruhy a kontexty s ciel'om vytvorit plnohodnotný obraz o šírke a rozmanitosti Procházkových kontaktov a záujmov. Upozornili tiež na niektoré špecifiká. Procházkov osobný alebo písomný kontakt s niektorými významnými hudobníkmi, ako boli D.-F.-E. Auber, H. Berlioz, M. I. Glinka, Ch. Gounod, N. Paganini, G. Rossini či G. Verdi, ktorých portrétne fotografie album obsahuje, nemožno nijako preukázat'. Z hladiska chronológie by u niektorých z nich vzájomný kontakt ani neprichádzal do úvahy, napríklad s Paganinim. To znamená, že čast’ portrétov v albume je výsledkom Procházkovho zberatel'ského úsilia. Na druhej strane prekvapuje, ako sa konštatovalo, že chýbajú portréty A. Dvořáka, R. Wagnera či polských hudobníkov, kedže Procházka bol vel'kým ctitelom tak Smetanu, ako Dvořáka a bol známy svojím slovanofilstvom. Do prvej časti publikácie patrí aj kodikologický popis pamiatky a edičné zásady, ako aj niekol'ko precízne zostavených prehladových tabuliek, ktoré z rôznych aspektov približujú obsah Procházkovho fotoalbumu a zároveň poskytujú vzorne prehladovú orientáciu v editovanej pamiatke. Na záver tejto časti je zaradená chronológia Procházkovho života a diela (s. xxxi - xxxii).

Druhá čast' publikácie predstavuje vlastnú edíciu s reprodukciami fotografií z Procházkovho fotoalbumu a muzikologickými komentármi (s. 1 - 165). Rámcová koncepcia je rovnaká ako v prvej publikácii: reprodukciu prameňa dopíňa muzikologická interpretácia. Vzhladom na odlišný typ pramenného materiálu musela sa, prirodzene, uplatnit modifikácia muzikologických riešení. V porovnaní $\mathrm{s}$ korešpondenciou, ak neberieme do úvahy komplikovanejšie prípady, z obsahu listu sú vztahy adresant - adresát, ako aj korelácia predmetu, ktorý ich spája, jednoznačné. Špecifikum pamiatok hudobnej ikonografie, 
v našom prípade $\mathrm{v}$ kategórii personálny portrét, spočíva $\mathrm{v}$ tom, že sú statickým obrazovo-vizuálnym dokladom istej skutočnosti. Editor či hudobný historik musí po identifikovaní a verifikovaní zobrazenej osoby alebo osôb získat údaje so zretelom na významové korelácie z iných zdrojov. Ak chýba akýkolvek záznam, dedikácia či aspoň podpis, je postup ešte náročnejší. Tu treba ocenit obdivuhodné penzum vedecko-výskumnej práce, ktorú editori venovali rešeršovaniu dobovej periodickej tlače, staršej aj novšej literatúry. Výsledné muzikologické komentáre $\mathrm{k}$ jednotlivým personálnym obrazovým jednotkám sú tak na úrovni hudobnohistorických mikroštúdií, ktorých názornost’ a detailnost' je skvelým príspevkom do mikrohistórie hudby.

$\mathrm{V}$ edícii sa postupuje abecedne podla priezviska zobrazenej osoby, resp. oficiálneho mena panovníka. Treba ocenit, že reprodukcie približujú fotografiu z obidvoch strán, tak averz ako reverz, kedže reverz poskytuje mnohé dôležité informácie, týkajúce sa rukopisných zápisov (venovanie a iné záznamy) aj tlačených údajov o fotoateliéri a jeho majitelovi. Prevažujú portrétne fotografie s jednou osobou, najmä typ tzv. vizitkových fotografií (carte de visite), sporadicky sa vyskytnú aj dvojportréty a celkom výnimočne zábery s viacerými osobami (sláčikové kvarteto, malé tableau). K niektorým osobnostiam sa zachovali dva fotografické snímky. Edícia obsahuje podobizne osobností ako D. A. Agrenev-Slavianskij, P. Augusti a manželka G. Vitali-Augusti, J. L. Bella, V. V. Bezekirskij, Č. Bubeníček, H. Richter, J. Durdík, Z. Fibich, O. Hostinský, W. Kienzl, P. Křížkovský, J. Lev, F. Liszt, K. J. Erben, J. N. Maýr, L. E. Měchura, F. Palacký, F. L. Rieger, J. Paleček, J. Pěch, N. Plotényi, J. A. Procházka (Procházkov otec), E. Reményi, K. Reményi, H. Richter, A. G. Rubinštejn, T. Sladovník, B. Smetana, E. Vašák či A. Wilhelmj. S Procházkovým slovanofilstvom možno spojit reprodukciu spomienkovej fotografie, vydanej roku 1863 na pamiatku národnej speváckej slávnosti v Brne 25. - 26. augusta 1863 pri príležitosti mileniálnych cyrilometodských osláv. Suplementom je komentár k shakespearovským slávnostiam v Prahe roku 1864, doplnený tromi portrétmi účastníkov týchto slávností (F. V. Jeřábek, J. Sklenář, E. Uggé), ktorí mali v rámci abecedného poradia už svoj samostatný profil. Výsledkom obdivuhodnej editorskej precíznosti a komparačnej dôslednosti je skutočnost', že z niekolkých desiatok známych aj menej známych osobností v albume zostalo neidentifikovaných iba sedem podobizní.

Obrazový materiál približuje prostredníctvom profesie fotografovaných osôb či už priamo alebo sprostredkovane $\mathrm{v}$ prvom rade hudobnokultúrne zameranie a prostredie, v ktorom Procházka pôsobil, a to aj v prípade, že by sme fotodokument zaradili do oblasti zberatel'ských aktivít, ako som spomenula vyššie. V rámci Procházkových spoločensko-kultúrnych kontaktov sa vo fotoalbume parciálne odráža aj jeho slovanofilská orientácia, ktorú možno odvodit od zastúpenia slovanských umelcov, ale aj od portrétu francúzskeho slavistu a bohemistu Louisa Legera či ruských cárov. Reflexie nad editovanou pamiatkou smerujú napokon $\mathrm{k}$ myšlienke, že fotoalbum odráža nielen bohatstvo a vrstevnatost' súvekej hudobnej kultúry, ale poskytuje aj jednu z možností, ako reálnejšie vnímat rozmanitost' a dynamiku hudobného života druhej polovice 19. storočia, ktorá pre súčasníkov znamenala ovela viac ako len „súčet“ vrcholných hudobných zjavov či velikánov, čo neskôr prešli „sitom dejín“.

Pri množstve dát, ktorými je edícia doslova nabitá, občas zaregistrujeme drobnú vecnú chybičku či nepresnost'. Môže to však byt' aj dôsledok prevzatia zaužívaného údaja z korektnej vedeckej literatúry, ktorý tvrdošijne žije svojím životom dalej. Uvediem jeden taký príklad. Treba korigovat údaj, že Franz Liszt vstúpil do duchovného stavu (s. 72). Starší slovenský historik františkán Vševlad J. Gajdoš OFM, ktorý skúmal špecifickú problematiku vzt̉ahu Liszta a jeho františkánstva, jednoznačne spresnil, že Liszt sa stal františkánskym konfrátrom, čiže čestným členom františkánskej rehole s právom nosit’ sutanu, ale bez reholných povinností. Nebol teda františkánskym terciárom, tzn. skutočným členom tretej rehole OFM.

Na záver by som rada opätovne zdôraznila, že editori Jana Vojtěšková a Jiří K. Kroupa 
mali nielen štastnú ruku pri výbere editovanej pamiatky, ale svojou úctyhodnou prácou a dôslednostou, kompetenciou a erudíciou pripravili pramenno-kritické vydanie, ktoré zodpovedá vysokým štandardom vedeckých edícií. Svojím záslužným muzikologickým činom obohatili pomerne málo zastúpenú oblast' hudobnej ikonografie a vedeckej dokumentácie. Precízne formulované mu- zikologické komentáre či hudobné profily $\mathrm{k}$ editovaným reprodukciám podobizní $\mathrm{z}$ fotoalbumu sú zároveň fascinujúcim čítaním $\mathrm{k}$ hudobným mikrodejinám, dávajúc podnet na úvahy, do akej miery môžu nové poznatky ovplyvnit postupné utváranie inovovaného obrazu hudobných dejín,

Jana Lengová

\section{Deníky Ludevíta a Marty Procházkových (1868-1888) / Die Tagebücher von Ludevít und Marta Procházka (1868-1888)}

K vydání připravili Jana VOJTĚŠKOVÁ, Jiří K. KROUPA. Praha : Národní muzeum \& KLP - Koniasch Latin Press, 2018. LX + 186 stran. ISBN 978-80-7036-579-3 (NM), ISBN 978-80-87773-61-1 (KLP)

V nedávnej dobe editori Jana Vojtěšková a Jiří K. Kroupa predložili odbornej aj širšej kultúrnej verejnosti d’alšiu spoločnú publikáciu Deníky Ludevita a Marty Procházkových (1868-1888), ktorá tematicky úzko súvisí s predchádzajúcimi dvoma kritickými edíciami prameňov a týka sa významnej osobnosti pražského hudobného života tretej tretiny 19. storočia Ludevíta Procházku a jeho manželky speváčky Marty Procházkovej. Píšeme o nich vyššie. Možno povedat', že všetky tri publikácie vytvárajú svojím predmetom bádania a editorským prístupom trojzväzkový, vzájomne sa doplňujúci komplet. Publikáciu vydalo Národní muzeum - České muzeum hudby v Prahe a pražské nakladatel'stvo KLP - Koniasch Latin Press s podporou Ministerstva kultúry ČR v rámci inštitucionálneho financovania koncepčného rozvoja výskumnej organizácie Národní muzeum. Vkusný výtvarný dizajn publikácie zachováva síce formát predchádzajúcich dvoch, avšak tentoraz namiesto dobovej úpravy preferuje moderné riešenie.

Pre hudobného historika je nielen potešujúce, ale aj vel'kou výzvou mat $\mathrm{k}$ dispozícii pramene toho typu, ako boli editované v troch spomínaných publikáciách. Je preto pochopi-

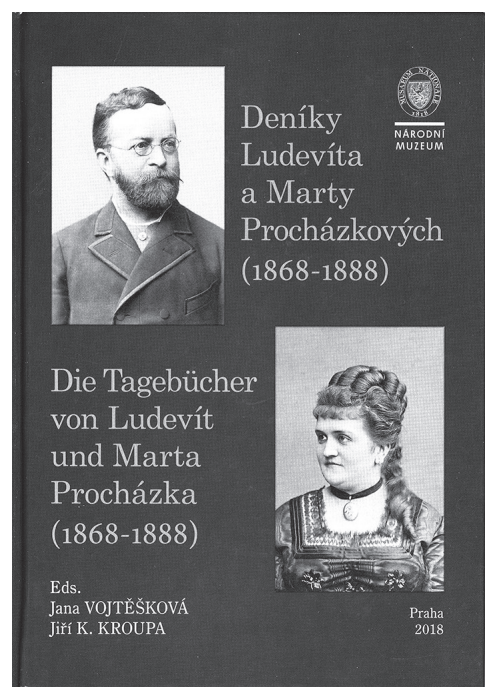

telné - a napokon to vidiet aj na výsledku -, že editori pristupovali k editorskej práci s maximálnym ludským aj muzikologickým zanietením a snahou prezentovat pramene ideálne na najvyššej vedeckej úrovni. V porovnaní s predchádzajúcimi dvoma publikáciami je prezentovaná pramenná edícia vydaná na kvalitnom, ale nie kriedovom papieri, čo zodpovedá štandardom textových publikácií. $\mathrm{Na}$ 